Економіка невизначеності: зміст, оцінювання, регулювання

\title{
МНОЖИННІСТЬ СЕНСІВ ЕКОНОМІКИ НЕВИЗНАЧЕНОСТІ ТА КОНЦЕПЦІЇ І МОДЕЛІ ПУБЛІЧНОГО УПРАВЛІННЯ
}

\author{
Радіонова Ірина Федорівна, \\ доктор економічних наук, професор, \\ ДВНЗ Київський національний університет імені Вадима Гетьмана, \\ ВНЗ «Університет економіки та права «КРОК», \\ ORCID: https://orcid.org/0000-0002-0941-2867
}

Анотація. Цей розділ присвячено уточненню змісту поняття «економіка невизначеності» та інших близьких до нього понять. Виокремлено та ідентифіковано явище меж економіки невизначеності й здійснено спробу обгрунтування параметрів, за якими можуть оцінюватися ці межі. Такими параметрами визначено: «не-волатильність», раціональність очікувань, конкурентність економічного середовища, релевантність економічної політики та рівень ії інституціоналізації. Сформульовано гіпотезу про визначальний напрямок змін концепції публічного управління, які мають відбуватися під впливом зростання масштабів економіки невизначеності. Наведено аргументи на користь того, що адекватна реакція публічної політики на розширення меж економіки невизначеності могла б спиратися на ідеї двох концепцій публічного управління. Це - концепція публічного врядування (Governance) та концепція економічного націоналізму.

Ключові слова: економіка невизначеності; економічна теорія невизначеності; невизначеність, спричинена економічною політикою; політична невизначеність; концепції та моделі публічного управління.

Предметом аналізу цього монографічного дослідження загалом і цього розділу зокрема $\epsilon$ економіка невизначеності. На початковому етапі дослідження зазвичай виникає необхідність якомога більш точного окреслення змісту понять, якими оперуватимемо у процесі вирішення наукової проблеми. Йдеться передусім про власне зміст та взаємозв'язки принаймні чотирьох понять, а саме:

- економіка невизначеності як теорія - «Economics of uncertainty»;

- економічна невизначеність як фрагмент національної економіки «Economic uncertainty»;

- економічна невизначеність, спричинена політикою уряду «Policy-related economic uncertainty»;

- політична невизначеність - «Policy uncertainty».

Економіка невизначеності як теорія, або «Economics of uncertainty», пояснює феномен економічної невизначеності з використанням певного теоретичного та аналітичного інструментарію: гіпотез, припущень, логічних конструкцій, узагальнень тощо. Призначенням цієї частини 
економічної науки, на наш погляд, є визначення критеріїв, меж, причин, форм утілення, наслідків, способів відтворення економічних відносин з ознаками невизначеності.

Економічна невизначеність як фрагмент (складник) національної економіки, або «Еconomic uncertainty», - це економічні відносини 3 особливими характеристиками, властивостями та маркерами (індикаторами), придатними для оцінювання. Саме ці характеристики, властивості, маркери мають досліджуватися в межах тієї частини загальної економічної теорії, що визначається як «Economics of uncertainty».

Тлумачення змісту економічної невизначеності зазвичай починається з ідентифікації тих станів, через які вона виявляється [1]. Йдеться, зокрема, про високі рівні інфляції та значну волатильність цін, занизькі темпи зростання або ж кризові спади економіки, безробіття, несподівані структурні зміни, очікування дефолтів, девальвації національної валюти тощо. При спробах кількісного оцінювання рівня невизначеності та її наслідків дослідники часто «обмежують» іiї зміст певним переліком конкретних показників, через які, за їх уявленнями, невизначеність можна ідентифікувати [2].

«Економічна невизначеність, пов'язана 3 політикою» («Policy-related economic uncertainty») віддзеркалює той незаперечний i економетрично доведений факт, що політика уряду впливає на темпи економічного зростання, глибину економічних спадів тощо. Важливо виокремлювати та ідентифікувати економічну невизначеність, пов'язану власне 3 політикою, ще й тому, що існує інша невизначеність. Це невизначеність, спричинена об'єктивно існуючою економічною циклічністю. Невизначеність, спричинена економічними циклами, виявляється у тому, що, попри усвідомлення невідворотності циклічних змін, важко або й неможливо безпомилково передбачити низку економічних параметрів. Ідеться про час проходження пікових точок у піднесеннях i спадах, а також про їх «глибину», про тривалість окремих фаз циклу тощо [3; 4]. Попри те, що існує достатньо досконалий економетричний інструментарій передбачення змін, його технічні, інформаційні тощо обмеження також формують економічну невизначеність.

«Політична невизначеність» («Policy uncertainty») може трактуватися передусім як дії уряду в економічній сфері, які не мають необхідного обгрунтування та організаційно-правового забезпечення.

Політичну невизначеність доцільно тлумачити як інституційну незавершеність у діяльності творців (стейкхолдерів) політики. Інституційна незавершеність може мати такі типові прояви, як лакуни законодавства, відсутність чітко окреслених суспільних цінностей, обгрунтованих 
стратегій і програм, а також політичної волі до їх реалізації. Ї̈̈ можуть підсилювати недоліки комунікації в управлінській ієрархії та у взаєминах влади з суспільством. Політична невизначеність, окрім згаданих вад інституціоналізації, об'єктивно пов'язана 3 політичними виборчими циклами, 3 непередбачуваною політичною реакцію суспільства й окремих спільнот на дії влади у процесі подолання техногенних, екологічних, епідеміологічних тощо викликів.

Феномен політичної невизначеності є настільки очевидним та суттєвим для суспільства, що існує напрямок досліджень, пов'язаний 3 обгрунтуванням i застосуванням методик оцінювання політичної невизначеності. До прикладу, в роботі Baker S., Bloom N., Davis S. презентовано конструкцію індексу невизначеності економічної політики (EPU - Economic Policy Uncertainty) [5]. Останній застосовано для оцінювання ситуації у США та ще дванадцятьох розвинених країнах. Показовим $\epsilon$ те, що економічна політика потрактована в цій роботі як певний симбіоз фіскальної, монетарної та регуляторної політики. Відтак, економічна політика, щодо якої оцінюється рівень невизначеності, фрагментована (структурована) за найважливішими інструментами урядового впливу на економіку.

Акцент на зв'язку економічної політики та економіки невизначеності $€$ особливо важливим у нашому дослідженні 3 двох причин. По-перше, тому що «публічне управління» - словосполучення, яке використано в назві цього розділу - і $є$ здійсненням певної економічної політики. По-друге, суб'єкти публічної влади в особі іiї центральних та місцевих органів, здійснюючи певну економічну політику, можуть або сприяти досягненню більшої економічної визначеності, або, навпаки, розширювати межі економічної невизначеності.

У взаємозв'язку двох понять (явищ) - «економічної невизначеності» та «політичної невизначеності» - друге стає причиною першого, а саме: політична невизначеність спричиняє та посилює економічну невизначеність. Хоча існують свідчення і зворотного зв'язку, коли економічна невизначеність посилює політичну.

Як уже зазначено, економічна теорія невизначеності - «Economics of uncertainty» - покликана відповісти на принципове питання про критерії та межі (масштаби) економіки невизначеності. Фактично, у такий спосіб може досягатися уточнення змісту цього поняття (явища).

Ми припускаємо, що економіка невизначеності є фрагментом будь-якої національної економіки. Для її ідентифікації необхідні певні критерії (параметри) оцінювання. Теоретична конструкція, пропонована нами для пояснення меж, відповідно, - змісту економіки невизначеності, подана на рис. 1. 
«Не-волатильність»

Якість інституціоналізації

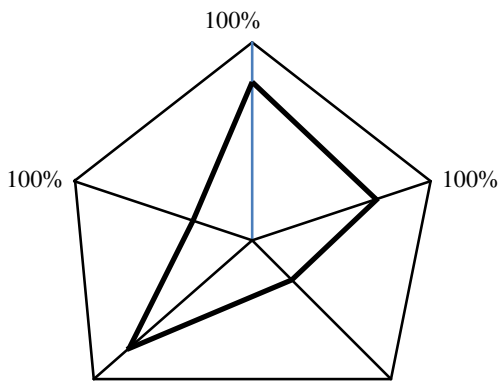

Раціональність

очікувань

Релевантність $100 \%$ політики

$100 \%$

«Конкурентність» середовища

\section{Рис. 1. Параметри і межі економіки невизначеності}

Джерело: розроблено автором самостійно.

За поданою на рис. 1 ідеєю, «економіка невизначеності»- це зона, що перебуває за межами фігури, окресленої чорним кольором. Усередині окресленої фігури знаходиться «зона визначеності», яка й формує осердя національної економіки. Наближення фактичних показників конкретної економіки, за п’ятьма параметрами, до позначки «100\%» означає, за нашою логікою, наближення до повної економічної визначеності. Натомість, віддалення від позначки «100\%» $є$ збільшенням зони економіки невизначеності.

Ми припускаємо, що зміст та межі економіки невизначеності як явища, об'єктивно притаманного будь-якій економіці, можуть визначатися за такими п'ятьма параметрами:

- «не-волатильність» економіки;

- раціональність очікувань економічних суб'єктів;

- конкурентність економічного середовища;

- релевантність економічної політики;

- якість інституалізації публічної влади.

Чи є підстави вважати, що перелік пропонованих параметрів для оцінювання невизначеності $€$ вичерпним? Звичайно, ні. Нові дослідження в цій царині виявлятимуть нові параметри та сприятимуть їх більш адекватній формалізації. Подовження й удосконалення переліку параметрів, імовірно, робитиме уявлення про економіку невизначеності більш обгрунтованими.

Для практичного застосування пропонованої теоретичної конструкції необхідна відповідь на питання про визначення так званої «точки перебування» в інтервалі від 0 до 100\% за кожним 3 п’ятьох пропонованих параметрів. Очевидно, що для цього можуть 
використовуватися прийоми оцінювання через порівняння, тобто бенчмаркінг. Останній, як відомо, передбачає виконання двох важливих передумов для відповідного застосування, а саме:

- наявність бази для порівняння;

- здійснення процедури нормування показників.

Базу для порівняння формують так звані стандартні значення показників. У якості таких можуть використовуватися кращі показники у відібраній для порівняння групі об'єктів або ж оптимальні значення показників, що визначені у вітчизняних або міжнародних нормативних документах та методиках.

Найпростішими формулами нормування, за якими може визначатися точка на інтервалі від 0 до 100\%, є ті, що фіксують міру відхилення фактичних значень параметрів від стандартних або ж відхилення фактичних значень від максимальних (мінімальних) у відібраній для порівняння групі об'єктів, а саме:

1) нормування показникастимулятора:

$$
\begin{aligned}
& y_{n}=\frac{x_{f}}{x_{s t}}, \\
& y_{n}=\frac{x_{\text {max }}-x_{f}}{x_{\max }-x_{\min }},
\end{aligned}
$$

2) нормування показникадестимулятора:

$$
\begin{aligned}
& y_{n}=\frac{x_{s t}}{x_{f}}, \\
& y_{n}=\frac{x_{f}-x_{\min }}{x_{\max }-x_{\min }},
\end{aligned}
$$

де $y_{n}$ - нормоване значення показника, $x_{f}$ - фактичне значення показника, $x_{s t}$ - стандартне (краще для певної групи, нормативне, оптимальне тощо) значення показника, $x_{\max }, x_{\min }-$ відповідно, максимальне та мінімальне значення показника у відібраній для порівняння групі об'єктів.

Більш складні формули нормування передбачають фактологічне обгрунтування й ідентифікацію певних інтервалів «нормальності» значень у таких межах, як, до прикладу, «оптимальне» та «задовільне», «задовільне» та «незадовільне», «незадовільне» та «критичне» тощо.

Залежно від того, у який спосіб формалізовано й репрезентовано стандартні (кращі, нормативні, оптимальні) значення, може застосовуватися або формула нормування для показника-стимулятора, або, навпаки, для показника-дестимулятора. Наприклад, у практиці управління застосовується показник «монопольної влади» для оцінювання стану певної сфери (ринку). Зрозуміло, що «конкурентність» та «монополізація» середовища $є$ протилежними за змістом явищами. Конкурентність звужує зону економіки визначеності, тобто є для неї дестимулятором. Натомість, монополізація розширює зону невизначеності, стаючи щодо неї стимулятором. 
Придатність пропонованої теоретичної конструкції (за рис. 1) до використання може обгрунтовуватися в процесі пояснення змісту та чинних практик (методик) вимірювання за п'ятьма згаданими параметрами: «не-волатильності», раціональності, конкурентності середовища, релевантності оцінювання та якості інституціоналізації.

Волатильність у найбільш загальному сенсі може тлумачитися як інтенсивність коливань, як збільшення міри відхилень (дисперсія) фактичних значень від сформованих трендів тощо. Відповідно, неволатильність має означати послаблення коливань та зменшення відхилень. Ідентифікація волатильності на національному і глобальному рівнях здебільшого здійснюється у формі інтегрального індексного оцінювання з визначенням відсоткової зміни (дисперсіі) певного індексу. Як правило, йдеться про індекси цін ринків, насамперед - фондових. За таким же підходом може визначатися дисперсія показників темпу економічного зростання, рівня безробіття, загального рівня цін тощо.

Зразок оцінювання волатильності з використанням індексів цін фондового ринку подано, наприклад, у роботі, яка присвячена індексу VIX та його порівнянню з іншими індексами волатильності - S\&P 100, $\mathrm{S} \& \mathrm{P} 500, \mathrm{VSTOOX}[6]$. Маючи показники волатильності, за відібраною для порівняння групою країн можна оцінювати відносний рівень волатильності національної економіки.

Раціональність очікувань, як параметр для оцінювання економіки невизначеності, спирається на одну з найбільш впливових економічних концепцій XX ст. - теорію раціональних сподівань. Як відомо, ідея раціональності в економічній сфері сформульована Muth J. у 1960-х роках. Вона була поширена й імплементована в макроекономічну теорію та теорію економічної політики видатними економістами Lucas R., Sargent T., Walles N. [7], Taylor J. [8] y 1970-x - 1990-x pp.

Дотичність ідеї раціональності до оцінювання економіки невизначеності пов'язана, на наш погляд, з такою обставиною. У теорії раціональних очікувань використовується фундаментальне припущення про те, що раціональність - це здатність на підставі доступної інформації передбачати те, що дійсно стається. Звідси випливає: чим вищий рівень раціональності, тим менша економічна невизначеність $\mathrm{i}$, навпаки, при збільшенні нераціональності у поведінці економічних суб'єктів, межі невизначеності мають розширюватися. Ми цілком погоджуємося $з$ узагальненням українського дослідника О. Ватаманюка, який влучно зауважив, що найбільша кількість відхилень від рачіональності фіксується саме у ситуаціях невизначеності, коли люди починають спрощувати для себе завдання вибору, керуючись певними «евристичними принципами» [9].

Важливо те, що феномен раціональності не лише аналізується 3 якісного боку, а й кількісно оцінюється. Маємо приклад оцінювання 
раціональності прогнозів МВФ та ОЕСР щодо дефіцитів бюджетів країн G7 на основі економетричних моделей. При цьому висновок про раціональність робиться на підставі вимірювання похибки прогнозів [10]. Такий підхід до кількісного оцінювання раціональності - за похибкою прогнозів - $\epsilon$ цілком обгрунтованим. Адже нездатність або обмежена здатність передбачати, відповідно, - збільшення похибки прогнозу є проявом нераціональності у тому первинному сенсі, який закладався творцями теорії раціональних сподівань.

Конкурентність економічного середовища є достатньо контроверсійним параметром в оцінюванні економічної невизначеності. На перший погляд, конкуренція, ототожнювана зі стихією ринку, мала б означати збільшення невизначеності. Натомість, монополія мала б пов'язуватися зі зростанням визначеності. 3 позицій економіки окремого суб'єкта, останнє твердження виглядає правдивим. Однак, з позицій усієї економіки, висновок мав би бути протилежним: масштаби економіки невизначеності збільшуються при згортанні конкуренції, при ускладненні умов провадження бізнесу, при збільшенні рівня монополізації. Це може обгрунтовуватися хоча б тим, що конкурентні умови - це певна передбачуваність результатів згідно із законами попиту та пропозиції. Натомість, монополізоване середовище породжує явище, яке можна охарактеризувати як «непередбачуваність домінування». Це невизначеність, пов'язана 3 неможливістю консенсусу загальних національних економічних інтересів. Відсутність консенсусу інтересів $\epsilon$ актуальним явищем української економіки, побудованої на засадах «олігархічної моделі». Остання означає монополізацію економічних сфер у поєднанні з домінуванням у політиці декількох олігархічних груп.

В арсеналі теорії галузевих ринків $є$ достатньо апробований інструментарій оцінювання того, що $є$ близьким за змістом до параметру «конкурентність економічного середовища». Йдеться, зокрема, про вимірник концентрації бізнесу на певному ринку (індекс ГерфіндаляГіршмана) та показник ринкової влади монополіста (коефіцієнт Лернера). Але згадані показники, що придатні для оцінювання окремої галузі (ринку), не задовольняють вимоги оцінювання всього економічного середовища. Більшою мірою такій вимозі відповідає оцінювання i ранжування країн світу за Індексом економічної свободи (Index of Economic Freedom). Останній, як відомо, розроблено за ініціативи Тhe Heritage Foundation and The Wall Street Journal та використовується вже 25 років поспіль [11].

На користь придатності Індексу економічної свободи для оцінювання конкурентності всього економічного середовища свідчить власне конструкція індексу. Він побудований на основі чотирьох складників-субіндексів, які віддзеркалюють важливі моменти формування конкурентного середовища. Такими є: 1) правові основи підприємництва; 
2) способи державного регулювання; 3) свободи економічних суб'єктів;

4) відкритість ринків. У методиці розрахунку Індексу економічної свободи йдеться про такі терміни та таке змістове наповнення чотирьох складників:

- «верховенство права» (права власності, судова ефективність, цілісність уряду);

- «масштаби уряду» (податкове навантаження на платників, державні витрати, фіскальна стабільність);

- «ефективність регулювання» (свобода підприємництва, свобода праці та грошового ринку);

- «відкритість ринку» (свобода торгівлі, інвестицій та фінансова свобода).

Використовуючи значення розрахованого для всіх країн світу (180 позицій) Індексу економічної свободи за конкретний рік, можна здійснювати процедуру нормування. Не виключено, що в якості стандарту можуть використовуватися найкращі світові значення індексу. В такий спосіб визначатиметься точка на осі від 0 до $100 \%$ за параметром «конкурентність економічного середовища».

Ми припускаємо, що в оцінюванні параметру «конкурентності економічного середовища» можна обмежитися певними складниками Індексу економічної свободи. До прикладу, це можуть бути лише два складники індексу, а саме: «ефективність регулювання» та «відкритість ринку». В будь-якому випадку, необхідним стає обгрунтування вибору на підставі певних припущень.

Релевантність політики - це ії відповідність «природі економічних процесів» і конкретним умовам, що склалися. Релевантність економічної політики може мати якісне (теоретичне) тлумачення та кількісне (фактологічне, емпіричне) оцінювання.

Якісне оцінювання релевантності економічної політики означає передбачення наслідків прийняття рішень у фіскальній, монетарній, зовнішньоекономічній тощо сферах на грунті певних теоретичних конструкцій (моделей). Такі модельні конструкції репрезентовані, зокрема, в кожному підручнику з макроекономіки. Вони ускладнюються 3 переходом від базового до вищого рівня макроекономіки остільки, оскільки в теоретичних моделях починає враховуватися ширше коло умов та припущень. Отже, теоретичне оцінювання релевантності політики $є$ порівнянням фактичних дій національних регуляторів економіки з логікою дій, за певними модельними конструкціями. Фактично, йдеться про відповідь на питання про ймовірні результати або втрати від економічної політики уряду, з урахуванням можливих інструментів впливу та певних обставин їх застосування, з огляду на логіку теоретичних моделей. 
Теоретичне оцінювання $\epsilon$ необхідним, але недостатнім для визначення рівня релевантності політики. Адже на його (теоретичного оцінювання) основі, можуть бути зроблені лише три висновки щодо політики: ймовірно, може бути «результативною», «мало результативною» або «не результативною». Зрозуміло, що лише такі три висновки щодо політики обмежують можливості оцінювання масштабів економіки невизначеності.

Прикладне, або емпіричне, оцінювання релевантності може існувати як складник так званого «циклу реалізації економічної політики». Для цього, як мінімум, має існувати сам «цикл політики» в діяльності уряду. Цикл зазвичай охоплює такі етапи: обгрунтування (ідентифікації цільових показників, інструментів впливу на економіку, оцінювання ресурсів), моніторингу, коригування, оцінювання результатів.

Про оцінювання, як про складник політичного циклу, йдеться, наприклад, в аналітичних матеріалах ОЕСР. Матеріали призначені для розробки особливого керівництва 3 самооцінювання країнами ОЕСР обгрунтованості державної політики (Draft Policy Framework on Sound Public Governance OECD) [12].

Якщо згадане керівництво 3 оцінювання обгрунтованості (релевантності) політики для країн ОЕСР виявляється заскладним для інших країн у повному його обсязі, то можливе його часткове використання. Йдеться, наприклад, про оцінювання через відхилення цільових показників фіскальної, монетарної, зовнішньоекономічної політики уряду від фактично досягнутих показників. У цьому випадку нормування може здійснюватися на основі припущення, що стандартними є саме цілььові значення показників. На користь такого припущення свідчить, зокрема, те, що досягнення визначених урядом цілей ідентифікується як найважливіша характеристика політики [13].

У дослідженні релевантності політики може бути використаний і підхід на основі оцінювання процедур політики. Сучасним прикладом такого підходу є міжнародний проєкт Digiwhist [14]. Його реалізація передбачає відносне (шляхом порівняння) оцінювання прозорості фіскальної сфери, а також дотримання тендерних процедур, успішності боротьби з корупцією у публічному секторі.

Ймовірно, що оцінювання релевантності політики на основі емпіричного дослідження обгрунтованості їі цілей та процедур мають бути не альтернативними, а взаємно доповнювальними підходами, тобто мають застосовуватися одночасно.

Якість інституалізації публічного управління - явище, що віддзеркалює процес реалізації політики. Інституалізація в публічному управлінні, за нашим припущенням, охоплює правила прийняття рішень у публічній сфері, процедури, алгоритми дій та нормативи 
стимулювання й обмеження, віддзеркалені у нормах права та забезпечені певними інститутами (організаційними структурами).

У науковому обігу перебувають достатньо відмінні визначення інституалізації [15]. Існують різні застосування цього терміна щодо різних сфер у різних країнах [16]. У цій монографії також подано розділ, присвячений інституціоналізації, а саме: інституційному дизайну макрофінансової безпеки [17]. Попри відмінності акцентів у визначеннях змісту інституціоналізації, здебільшого вона пов'язується з правилами, процедурами, правом, інститутами (організаційними структурами) влади.

Для кількісного оцінювання рівня інституціоналізації може використовуватися конструкція Індексу глобальної конкурентоспроможності (Global Competitiveness Index - GCI). ' Останній $є$ інтегральним вимірником, створеним під егідою Світового економічного форуму (World Economic Forum). Індекс охоплює 103 показники, об'єднані у 12 груп для визначення 12-х субіндексів. Перший із субіндексів інтегрального індексу GCI називається «Інститути» («Institutions») i, на наш погляд, може використовуватися для оцінювання пропонованого нами показника «Якість інституціоналізації».

За пропонованою Світовим економічним форумом методикою, субіндекс «Інститути» охоплює загалом 21 показник, 16 з яких стосуються інститутів саме публічної влади, а інші 5 - приватних інститутів. Власне оцінювання інститутів публічної влади, яке нас цікавить, передбачає виокремлення п’ятьох груп показників 3 такими означеннями та змістом:

- «майнові права» (захист прав власності загалом та інтелектуальної зокрема);

- «етика та корупція» (корупційне використання державних коштів, довіра до влади, корупційні виплати і хабарі);

- «неправомірні впливи» (незалежність судової системи та фаворитизм у державних рішеннях);

- «результативність державного сектору» (марнотратство у державних витратах, тягар державного регулювання, результативність правової бази при вирішенні суперечок та оскарженні рішень, прозорість формування публічної політики);

- «безпека» (бізнес-витрати на тероризм, злочини та насильство, масштаби організованої злочинності, надійність поліції).

Використання даних про зміну місця країни у світовому рейтингу за статтею «GCI 4.0: Pillar 1: Institutions» дає можливість здійснювати нормування, припускаючи, наприклад, що стандартом $є$ значення субіндексу кращої країни. До прикладу, таке порівняння мало б

* Інституційний дизайн макрофінансової безпеки для стабілізації національної економіки. 
ураховувати те, що місце України, за субіндексом «Інститути», змінювалося у 2017, 2018 та 2019 роках, відповідно, так: 115, 110 та 104 місце [18].

Економічна політика та моделі публічного управління не можуть не реагувати на економічну невизначеність. На користь цього твердження свідчить, зокрема, помічений дослідниками зв’ язок: збільшення невизначеності зменшує довіру до національних регуляторів (до прикладу, до центрального банку). Це спричиняє макроекономічний наслідок у вигляді скорочення витрат домашніх господарств і підприємцівінвесторів [19].

Непередбачуваність ситуації, пов’язаної з «Covid-19», викликала новий інтерес до проблеми економічної невизначеності. Більш детально стали досліджуватися не лише їі прояви в економіках окремих країн [20], а й реакції публічної влади на зростання невизначеності, а також досвід протидії економічній кризі з боку національних урядів [21].

Реагування публічної влади на посилення економічної невизначеності мало б розпочинатися 3 імплементації безпекового параметру в систему першочергових цінностей. Ідеться не тільки про реагування національних регуляторів на зміни окремих показників економічної безпеки. Ймовірно, що на часі створення концепції публічного управління, яка б віддзеркалювала факт нових масштабів економіки невизначеності. У руслі створення такої концепції проблема оцінювання масштабів невизначеності, відповідно, відбору параметрів для оцінювання стає першочерговою. Тому наша спроба обгрунтування конкретних параметрів - «не-волатильності», раціональності очікувань, конкурентності середовища, релевантності політики та якості інституціоналізації - може розглядатися як один з кроків на шляху до створення такої концепції.

Так званий безпековий параметр як цінність (і мета) публічної влади в контексті оптимізації масштабів економіки невизначеності, 3 урахуванням пропонованих нами параметрів, мав би виявлятися у таких діях:

- запобігання та протидія загрозливій для цілісності національної економіки волатильності;

- формування раціональних очікувань, передусім через збільшення довіри до дій влади та її здатності передбачати перебіг подій;

- обмеження монополізму та сприяння конкурентності економічного середовища;

- формування обгрунтованого, тобто релевантного, політичного циклу 3 послідовними та передбачуваними діями національних регуляторів;

- дотримання правил, процедур та визначених владою нормативів у економічній сфері.

Якщо безпека, ідентифікована як оптимізація масштабів невизначеності, ставатиме пріоритетом (метою) публічної влади, то це 
може змінювати економічну політику концептуально. Адже йтиметься про формування нового альтернативного вибору, відповідно - про врахування модифікованих координат політики. В якості таких координат, на наш погляд, можуть розглядатися: «Добробут (соціальна захищеність)», «Розвиток (інвестиції та інновації)», «Безпека (економічна визначеність)». Взаємозв'язок згаданих альтернативних цілей i, відповідно, координат політики подано на рис. 2.

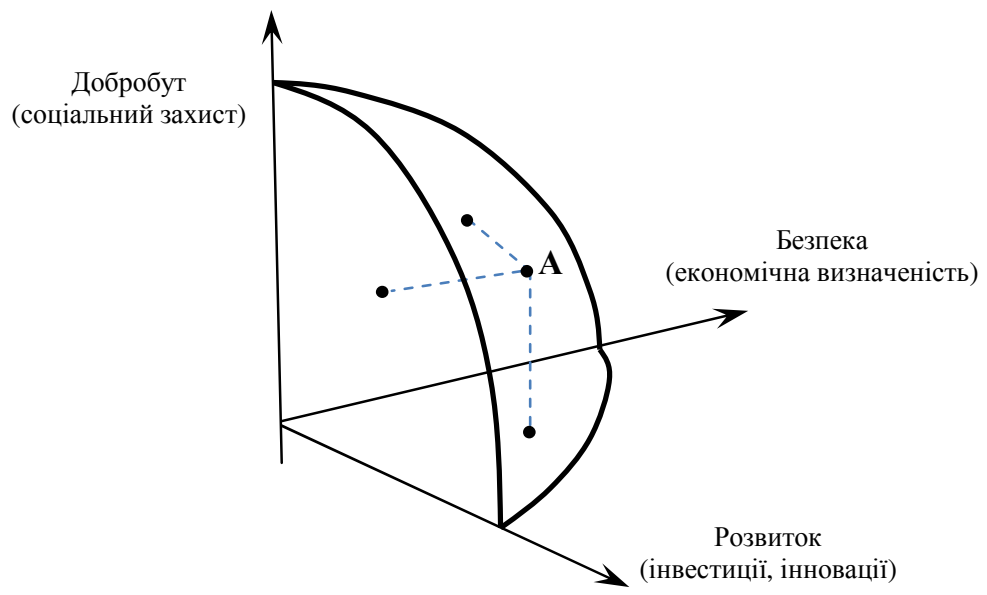

Рис. 2. Модель економічної політики як результату вибору в координатах трьох цілей

Джерело: створено автором самостійно.

На рис. 2 презентовано ідею про формування економічної політики $з$ урахуванням трьох цілей. Дві 3 них - «Добробут (соціальна захищеність)», «Розвиток (інвестиції та інновації)»- можна вважати «традиційними». Їх традиційність виявляється у тому, що зазвичай в якості альтернатив для ілюстрації вибору, за обмежених ресурсів, розглядаються товари «для споживання» та товари «для інвестування». Таке припущення, зокрема, використовувалося в теоретичній конструкції 3 назвою «функція соціального добробуту» («Social welfare function») або ж «крива суспільної байдужості» (Community indifference curve) [22]. Зрозуміло, що «товари для споживання» корелюють 3 поняттям «добробут», а «товари для інвестування» - 3 поняттям «розвиток». Третя ціль - «Безпека (економічна визначеність)» - не $\epsilon$ «традиційною». Вона не використовується у відомих теоретичних конструкціях: а) для пояснення суспільного вибору, б) поряд з двома іншими цілями в якості третьої компоненти вибору. 
Фундаментальні ідеї, покладені в основу теоретичних конструкцій «функції соціального добробуту» та «кривої суспільної байдужості», на наш погляд, можуть використовуватися для ілюстрації прийняття рішень публічною владою при виборі з урахуванням трьох цілей.

У пропонованій нами теоретичній конструкції (рис. 2) кожна 3 трьох кривих (і функцій) виконує таку пояснювальну роль:

- ілюструє межу можливостей, перевищення якої недосяжне, 3 огляду на наявні ресурси;

- $є$ геометричним місцем точок, кожна 3 яких презентує один 3 варіантів вибору з двох альтернатив, які (варіанти) $є$ однаково корисними для учасників політичного процесу.

За змістом координат, у яких побудовано три криві, їх можна було б визначати так:

- «функція соціальних можливостей» (у координатах: «Добробут (соціальна захищеність)» - «Розвиток (інвестиції та інновації)»);

- «функція виробничих можливостей» (у координатах: «Розвиток (інвестиції та інновації)» - «Безпека (економічна визначеність)»);

- «функція безпекових можливостей» (у координатах: «Безпека (економічна визначеність)»- «Добробут (соціальна захищеність)»).

Проблема оптимального вибору за трьома цілями політики, як ілюстровано на графіку рис. 1, пов'язана не з наближенням до так званих «кривих можливостей», а 3 рухом у бік площини, утвореної цими кривими. Фактично, постає завдання «не-виходу» за об'єктивні межі, окреслені трьома кривими, які утворюють складну площину. Складність знаходження параметрів точки вибору (точка А на рис. 2), що максимально наближалася б до цієї площини, лишень ілюструє більшу складність вибору «за трьома цілями» у порівнянні з вибором «за двома цілями».

На грунті сформованих уявлень про зміст економіки невизначеності можна оцінювати концепції (моделі) публічного управління, за їх придатністю відповідати на виклики невизначеності. У зв'язку з цим доцільно розрізняти два прояви невизначеності, а саме: невизначеність у процесах; невизначеність у результатах.

На наш погляд, найбільш адекватну реакцію системи управління на невизначеність у економічних процесах забезпечує концепція публічного управління Governance. Ймовірно, що найближчим українським відповідником цього англійського терміна $є$ термін «концепція публічного врядування».

Власне концепції публічного врядування Governance історично й логічно передувала інша концепція - Governvent. Українським відповідником останньої $є$ «державне управління».

Попри те, що згадані концепції - Governvent та Governance пов'язані між собою, вони мають принципові відмінності. Їх 
пов'язаність виявляється у тому, що обидві вони є управлінськими, реалізуються в публічній царині та стосуються одного об'єкта економіки - на загальнонаціональному (макроекономічному) рівні.

Відмінності між Governvent та Governance пов'язані передусім зі співвідношенням змістів близьких, але не тотожних понять (явищ), а саме: «публічне» та «державне», «врядування» та «управління». Оскільки власне уточнення змісту згаданих понять виходить за межі нашого дослідження, ми лише репрезентуємо своє бачення цього співвідношення у стислому (формалізованому) вигляді. На наш погляд, співвідношення може подаватися так:

$$
\begin{gathered}
\text { «публічне»> «державне», } \\
\text { «врядування»> «управління». }
\end{gathered}
$$

Особливий зміст концепції публічного врядування Governance найкраще виявляється при його порівнянні зі змістом концепції державного управління Governvent. Це порівняння подано на рис. 3.

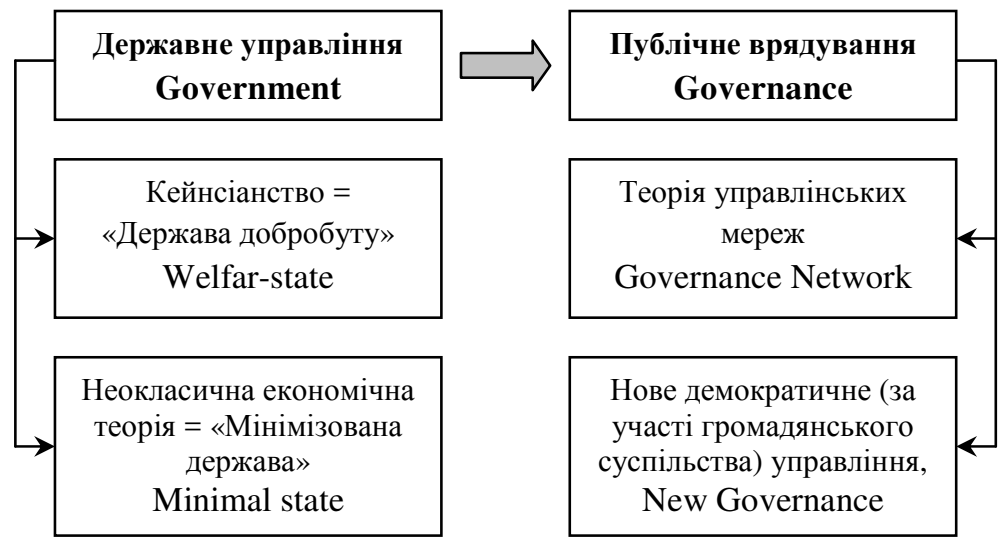

\section{Рис. 3. Порівняння концепцій управління економікою на загальнонаціональному рівні}

Джерело: створено автором самостійно.

Перехід від концепції державного управління (Government) середини XX ст. до концепції публічного врядування (Governance) 1990-х - початку XX ст. стимульований так званими «лакунами» або «провалами» держави. Йдеться про те, що традиційне управління середини XX ст. дедалі більше виявляло часткову неспроможність держави у вирішенні низки економічних та соціальних проблем. Тому виникає потреба у формуванні нових підходів до публічного управління на загальнонаціональному рівні та у впровадженні нових практик управління. 
Принципові відмінності між Government та Governance можна ідентифікувати на основі порівняльного аналізу тих теорій, які складають основний зміст двох альтернативних концепцій.

Концепція Government, попри відмінності кейнсіанства та неокласичної теорії, на основі яких вона розвинулася, в обох випадках дає відповіді на подібні питання, а саме:

- за створення яких суспільних благ має відповідати держава, які ресурси при цьому можуть використовуватися, відтак, якими $є$ об'єктивні економічні межі держави;

- 3 використанням яких інструментів мають досягатися визначені урядами цілі економічної політики, які інструменти державного регулювання та в яких випадках виявляють найбільшу результативність, а в яких, навпаки, стають недоречними;

- як мають поєднуватися в економічній політиці урядів фіскальні, монетарні та регуляторні (адміністративні) інструменти, яких правил політики при цьому доцільно дотримуватися.

Концепція Governance стосується дещо інших, порівняно 3 Government, управлінських акцентів. Попри це, в практиці реалізації ідей Governance не можна уникнути використання надбань концепції Government. Особливо, це стосується сформульованих правил застосування інструментів державного регулювання економіки, а також передбачення та оцінювання економічних результатів діяльності урядів.

Загальні засади концепції Governance віддзеркалено в документах ЄC. Ідеться, наприклад, про звіт, у якому подано фундаментальні принципи управління на засадах Governance. Це - принципи відкритості, участі, підзвітності, ефективності та узгодженості дій [23]. 3 цього переліку випливає висновок про акцентування уваги в теоретичному інструментарії концепції Governance саме на процесуальному аспекті управління.

Особливості концепції Governance розкриваються у численних джерелах [24; 25], зокрема, присвячених аналізу теорій, що формують іiї зміст. Це - теорія управлінських мереж (Governance Network) [26] та теорія нового демократичного управління з залученням громадянського суспільства (New Governance [27]).

Найбільш оригінальні ідеї-відповіді щодо принципових питань організації управлінського процесу, які сформувалися в межах згаданих теорій (Governance Network та New Governance), на наш погляд, є такими:

- дотримання правил, алгоритмів, проиедур доцільної взаємодії суб'єктів політики, а також демократичність процедур апріорі робить іiі (політику) ефективною;

- політика має оцінюватися не стільки за економічними та соціальними результатами, скільки за якістю дотримання процедур; 
- економіка потребує не керування, а спрямування з боку органів влади, які покликані формувати багаторівневі зв'язки (мережі), що охоплюють та імплементують в управлінський процес не лише органи влади, а й громадянське суспільство;

- демократичність процедур досягається через численні інструменти участі громадян - публічні дебати, громадські ініціативи, соціологічні дослідження щодо можливих реакцій на дії влади та щодо очікувань спільнот тощо;

- одним 3 ефективних засобів дотримання демократичності управлінських процесів стає використання цифрових технологій та формування системи електронного врядування (e-Governance [28]).

Ми припускаємо, що більший потенціал концепції Governance щодо адекватного реагування на виклики зростання масштабів економіки невизначеності пов'язаний 3 так званим «розширенням змістів». Це «розширення» ілюстровано на рис. 4.

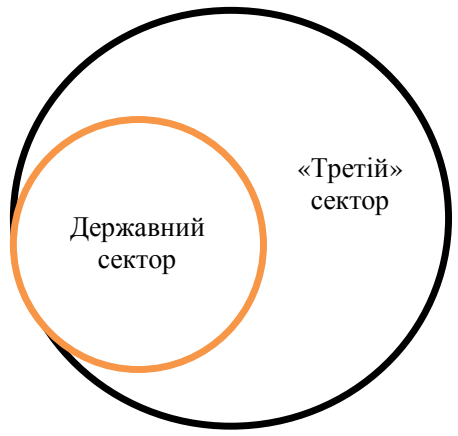

Рис. 4а. Публічна сфера

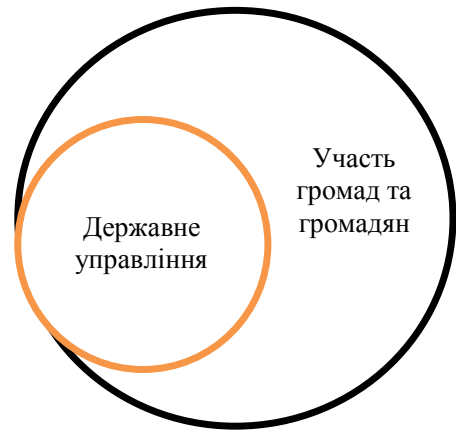

Рис. 4б. Врядування

Рис. 4. «Розширення змістів» у межах концепції публічного врядування Governance

Джерело: створено автором самостійно.

На рис. 4 візуалізовано ідею про те, що концепція (і практика) Governance подає управлінський процес «у ширшому сенсі». Тобто, йдеться про трактування публічної сфери у складі й державного, і «третього» (громадянського) сектору. Відповідно, врядування трактується як поєднання й системи державного управління, й системи участі громадян у публічному управлінні. Відтак, формується додатковий сегмент і додаткові можливості реагування на економічну невизначеність.

Обгрунтованість ідеї «розширення змістів» можна аргументувати, спираючись на факти і приклади обмеження невизначеності в українській 
економіці. Маємо на увазі те, що економічна неспроможність Української держави в найбільш критичні моменти невизначеності компенсується участю українського суспільства. Громадянське суспільство перманентно використовує різні форми компенсації економічної неспроможності держави. Йдеться про «самокошт» для інноваційних та безпекових проєктів, благодійництво та волонтерство в соціальному захисті населення при недофінансуванні медицини, освіти, культури, а також у сфері національної безпеки, при бездіяльності органів влади щодо запобігання економічним злочинам тощо.

Адекватне реагування на невизначеність результатів, на наш погляд, забезпечується практичним використанням ідей концепції економічного націоналізму.

Як відомо, концепція економічного націоналізму сформувалася в межах «історичної школи» економіки XIX ст. Для обгрунтування придатності цієї концепції відповідати на виклики економіки невизначеності доцільно зосередити увагу на двох обставинах. Поперше, на історичних умовах, в яких формувалися й «історична школа» загалом, і концепція економічного націоналізму зокрема. Подруге, важливо поглянути на ідеї засновника концепції економічного націоналізму Фрідріха Ліста під кутом зору тих висновків, які мають прикладну цінність і сьогодні.

«Історична школа» економіки виникає на теренах Німеччини першої половини XIX ст. саме в той час, коли для країни актуалізуються декілька проблем невизначеності результату. Йдеться, по-перше, про збереження національної ідентичності та економічної цілісності країни. По-друге, життєво важливим стає опанування певного місця у світовій економіці на тлі домінування індустріально розвиненої імперської Англії. Зрозуміло, що пануюча на той час концепція лібералізму й вільної торгівлі, пропонована англійською школою класичної політичної економії, не могла відповідати національним інтересам економічно слабкої Німеччини.

У науковому спадку засновника концепції економічного націоналізму Ф. Ліста (1789 - 1846) знаходимо низку ідей, які не втратили своєї важливості, крім іншого, й тому, що активно втілювалися впродовж XX ст. та продовжують втілюватися донині. Ці ідеї й ці практики стали достойною альтернативою ліберальним поглядам. Вони успішно використовувалися амбітними країнами, які долали відставання у соціально-економічному розвитку та наслідки економічного колоніалізму [29]. Проблема економічного колоніалізму, у поєднанні з високим рівнем економічної невизначеності, залишається актуальною для української економіки в XXI ст. 
Ідеї концепції економічного націоналізму в роботах Ф. Ліста" та пов'язані з ними узагальнення щодо економічної невизначеності, які 3 цих ідей випливають, на наш погляд, можуть бути подані так:

1. Iдея: економіка кожної країни розвивається за особливими законами, реалізація яких покликана забезпечити розвиток продуктивних сил саме конкретної нації в конкретний час.

Висновок: спроба реалізації загальних, а не особливих законів на конкретних теренах може спричиняти гальмування розвитку національних продуктивних сил та посилення економічної невизначеності.

2. Iдея: продуктивні сили нації не обмежуються лише матеріальними складниками - засобами виробництва та природними ресурсами. Вони охоплюють і додатково набуті здібності людей, а також систему урядування, мораль, мистецтво, судочинство. Важливим чинником економічного зростання стає «духовне знання» остільки, оскільки воно сприяє формуванню нових продуктивних сил.

Висновок: брак матеріальних продуктивних сил та пов'язана 3 цим невизначеність, властива країнам з нижчим рівнем розвитку, може компенсуватися використанням потенціалу суспільних інститутів й інститутів державної влади.

3. Ідея: економічна політика уряду має бути активною i наступальною. Важливим проявом активізму держави стає «виховний протекціонізм», стимулювання вітчизняного виробництва та обмеження імпорту в задоволенні національних потреб. Завданням уряду має бути інвестування в інфраструктуру, узгодження взаємодії окремих ланок національної економіки.

Висновок: розвиток національної економіки, як передумова вищого рівня економічної визначеності, забезпечується державою, наділеною функціями захисту, стимулювання, гарантування цілісності національної економіки.

4. Iдея: теорія і практика «вільної торгівлі» стає інструментом економічного домінування більш економічно розвинених націй щодо тих, які мають нижчий рівень розвитку. «Вільна конкуренція між двома цивілізованими націями, - писав Ф. Ліст 170 років тому, - може

\footnotetext{
* Дослідником економічного колоніалізму стосовно України був відомий у світі, але маловідомий в Україні, американський професор українського походження Всеволод Голубничий. Його робота «Теорія економічного колоніялізму та ії стосунок до України» введена в науковий обіг завдяки дослідженню українських науковців, репрезентованому в роботі «Політична економія суспільного прогресу» Всеволода Голубничого у двох томах [30].

Для презентації ідей Ф. Ліста ми скористалися роботою Злупка С. М. [31, с. 354-372] у частині, присвяченій Німецькій історичній школі. Згадана робота цікава тим, що ії автор не лише спирається на оригінальну роботу самого Ф. Ліста (Лист Ф. Национальная система политической экономии. СПб, 1891), а й використовує аналіз цієї історичної спадщини німецьких вчених та докторську роботу українського науковця, виконану в Українському Вільному Університеті в Мюнхені (Німеччина).
} 
бути взаємно корисною лише тоді, коли вони перебувають приблизно на одному рівні промислового розвитку...».

Висновок: застосування на практиці принципів вільної торгівлі для національних економік з нижчим рівнем розвитку може спричиняти консервування відставання та посилення економічної невизначеності.

Аргументи на користь придатності концепції економічного націоналізму для використання при досягненні вищого рівня розвитку та більшої визначеності економічних результатів знаходимо в успішних моделях економічного відродження окремих країн. ${ }^{* *}$ Аналіз національних моделей з позицій реалізації лише двох ідей економічного націоналізму національної єдності як джерела для розвитку продуктивних сил та активності держави у реалізації національних економічних проєктів подано в аналітичній табл. 1.

Таблиця 1

\section{Дві $з$ ідей концепції економічного націоналізму в моделях публічного управління окремих країн}

\begin{tabular}{|c|c|}
\hline $\begin{array}{l}\text { Ідеї концепції } \\
\text { економічного } \\
\text { націоналізму }\end{array}$ & $\begin{array}{c}\text { Приклади реалізації ідей концепції економічного } \\
\text { націоналізму в успішних моделях відродження } \\
\text { національних економік }\end{array}$ \\
\hline \multirow[t]{3}{*}{$\begin{array}{c}\text { Національна єдність, } \\
\text { подолання соціального } \\
\text { відчуження як } \\
\text { «додаткова продуктивна } \\
\text { сила» та джерело } \\
\text { економічного зростання }\end{array}$} & $\begin{array}{l}\text { Модель «Державного соціалізму» в Німеччині } 1880-x- \\
1890-x \text { рр. за часів Отто фон Бісмарка: подолання відчуження } \\
\text { робітничого класу та його опозиції до Німецької держави } \\
\text { шляхом ухвалення і реалізації низки законів соціального } \\
\text { захисту в царині медицини (1883), пенсійного страхування } \\
\text { (1889), захисту праці (1891).*** }\end{array}$ \\
\hline & $\begin{array}{l}\text { Модель «Етичного (конфуціанського) капіталізму» першої } \\
\text { третини ХХ ст., за часів японського лідера Е. Shibusava: } \\
\text { подолання відчуження через формування «позитивної } \\
\text { ідентичності національного бізнесу» шляхом створення ним } \\
\text { у взаємодії з японською державою благодійних організацій, } \\
\text { реалізації соціальних програм, зокрема, оновлення системи } \\
\text { шкільництва тощо [34]. }\end{array}$ \\
\hline & $\begin{array}{l}\text { Модель «Французького солідаризму» П'ятої Республіки } \\
\text { після прийняття Конституції } 1958 \text { р., за президентства } \\
\text { Шарля де Голля: вибіркова підтримка найбільш економічно } \\
\text { відсталих регіонів, подолання відчуження між суспільними } \\
\text { верствами через «систему участі», «соціальні ліфти», } \\
\text { включно з «ліфтами» у системі державної служби, реформування } \\
\text { освітньої системи в напрямку гарантування якісної освіти } \\
\text { для всіх [35]. }\end{array}$ \\
\hline
\end{tabular}

\footnotetext{
* В аналізі використана робота Панченка В. [32, с. 6-12] у частині «Теоретичні підвалини економічної доктрини ОУН, або Ф. Ліст проти К. Маркса».

** Переклад В. Панченка з List Frederik National System of Political Economy. Philadelphia: J. B. Lippincott \& Co, 1856. P. 77.

**** Узагальнюючі матеріали про успішні моделі на засадах економічного націоналізму подано в роботі Аналітичного центру «Українські студії стратегічних досліджень» [33].
} 
Продовження табл. 1

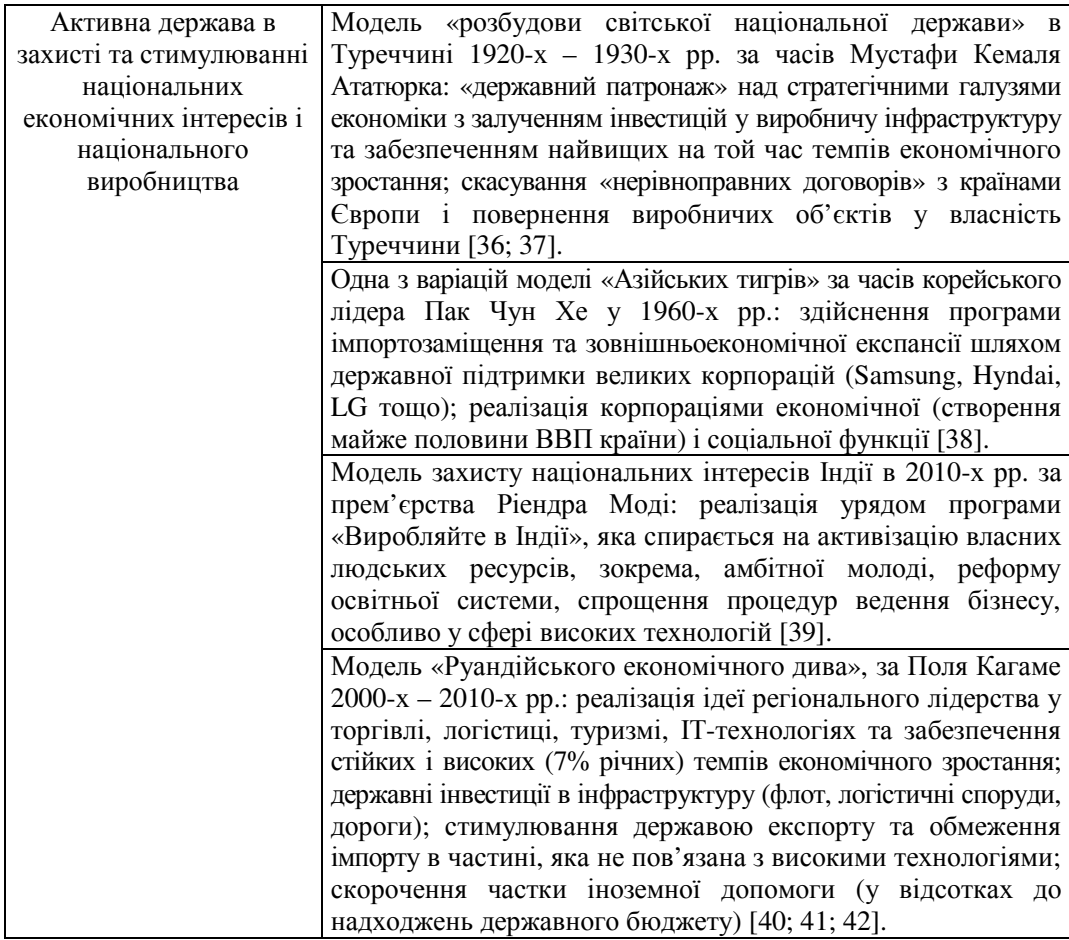

Джерело: створено автором самостійно.

Перелік успішних моделей публічного управління зі складниками ідеями, інструментами, організаційними практиками, - які відповідають концепції економічного націоналізму, міг би бути продовженим, а аналіз - поглибленим. У контексті теми нашого дослідження важливо те, що ці численні факти дійсно існують і що вони стосуються успішних країн. Термін «успішна країна» означає досягнення бажаного результату соціально-економічного розвитку. Це має інтерпретуватися як те, що концепція економічного націоналізму сприяє обмеженню невизначеності саме за критерієм отриманого результату.

\section{Висновки:}

Власне поняття «економіка невизначеності» віддзеркалює факт об'єктивного існування відносин 3 особливими характеристиками. Останні ідентифікуються та якісно оцінюються «економічною теорією невизначеності» - особливим напрямком досліджень в економічній науці. Остільки економічну невизначеність посилює або, навпаки, нівелює 
економічна політика, оскільки стає доцільним виокремлення поняття «економічна невизначеність, спричинена політикою». Економічну невизначеність спричиняє політика з ознаками невизначеності, або «політична невизначеність». Усвідомлення зв'язків між економічною та політичною невизначеністю створює підгрунтя для висновків у царині концепцій та моделей публічного управління.

Ідентифікація економіки невизначеності передбачає використання параметрів для її якісного визначення та оцінювання. 3 цією метою, на наш погляд, можуть використовуватися такі параметри, як волатильність економіки, раціональність очікувань економічних суб'єктів, конкурентність середовища, релевантність економічної політики та рівень іiі інституціоналізації.

У кількісному оцінюванні масштабів економіки невизначеності можуть використовуватися бази порівняльних даних, створених для розрахунку інтегральних індексів міжнародних організацій. Ідеться, зокрема, про субіндекси Індексу економічної свободи та Індексу глобальної конкурентоспроможності. Базою для оцінювання мають також ставати дані національної статистики щодо економічного зростання, коливання рівня цін та зайнятості, фондових індексів тощо.

В якості ймовірного адекватного способу реагування теорії і практики публічного управління на збільшення масштабів економіки невизначеності може розглядатися імплементація безпекового параметра в координати й цілі економічної політики. При цьому безпековий параметр має інтерпретуватися як обмеження економічної невизначеності.

В економічній теорії та в теорії публічного управління вже створені концепції й відповідні ідеї, які, у випадку практичної реалізації, можуть забезпечувати адекватне реагування на розширення масштабів економіки невизначеності. Це, по-перше, концепція публічного врядування 3 ідеєю розширення змістів управління за рахунок «третього сектору» та участі суспільства в реалізації «циклу економічної політики» (Governance). По-друге, це концепція економічного націоналізму з ідеями активної держави у захисті національних економічних інтересів, у створенні суспільних інститутів розвитку національних продуктивних сил і подолання економічного відставання.

Актуальними напрямками майбутніх досліджень у царині економіки невизначеності можуть стати: подальше уточнення множинних сенсів економіки невизначеності, ідентифікація та класифікація форм іiї прояву, вдосконалення інструментарію для оцінювання їі масштабів, узагальнення щодо нових способів реагування на економічну невизначеність у різних національних моделях публічного управління.

\section{Jimepamypa:}

1. Pettinger T. Economic uncertainty. Economics Help. URL : www.economicshelp.org. 
2. Jackson L., Kliesen K., Owyang M. The Nonlinear Effects of Uncertainty Shocks. Federal reserve bank of st. Louis.

3. Research Division P.O. Box 442 St. Louis, MO 63166. Working Paper 2018-035B. url : https://doi.org/10.20955/wp.2018.035.

4. Robert Lensink, Hong Bo., Elmer Sterken Does uncertainty affect economic growth? An empirical analysis Faculty of Economics University of Groningen, Netherlands. URL : https://link.springer.com/ content/pdf/10.1007/BF02707331.pdf.

5. Yonghong JIANG Y., Juan MENG J., NIE H. Visiting the economic policy uncertainty shocks - economic growth relationship: waveletbased granger-causality in quantiles approach. Romanian Journal of Economic Forecasting - XXI. 2018. №(2). P. 80-94. URL : http://www.rjef. ro/rjef/rjef2_18/rjef2_2018p80-94.pdf.

6. Baker S., Bloom N., Davis S. Measuring economic policy uncertainty. National Bureau of Economic Research. Working Paper. 2015. №21633. URL : http://www.nber.org/papers/w21633.

7. Moran M., Liu B. The vix index and volatility-based global indexes and trading instruments. CFA Institute Research Foundation. 2020. URL : https://papers.ssrn.com/sol3/papers.cfm?abstract_id=3668983.

8. Sargent T., Walles N. Rational expectations and the theory of economic policy. Journal of Monetary Economics. 1976. №2. P. 169-183. URL : https://EconPapers.repec.org/RePEc:eee:moneco:v:2:y:1976:i:2:p:169-183.

9. Taylor J. How the Rational Expectations Revolution Has Changed Macroeconomic Policy Research. 1999. Stanford university. Revised Draft: February 29. 2000. URL : https://web.stanford.edu/ johntayl/Papers/IEA Lecture.pdf.

10. Ватаманюк О. 3. Бізнес-економіка. Львів : ЛНУ імені Івана Франка, 2018. 324 с.

11. Elliott G., Caltech I., Timmermann A. Estimation and Testing of Forecast Rationality under Flexible Loss. Review of Economic. 2005. №72. P. 1107-1125: https://rady.ucsd.edu/faculty/directory/timmermann/pub/docs /forecast-rationality.pdf

12. The fraser institute: annual report «economic freedom of the world». URL : https://ueff.org/en/indices/78-the-heritage-foundation-the-indexof-economic-freedom.

13. Draft Policy Framework on Sound Public Governance. Preliminary version. OECD. 2018. P. 77.

14. Van der Meer F-B New Public Management and Evaluation. In book: New Public Management in Europe. 2007. P. 165-180.

15. Digiwhist - Erca. URL : www.againstcorruption.eu > digiwhist.

16. Keman H. Institutionalization social process. Article: institutionalization Definition, Sociology, \& Theories. Britannica. URL : www.britannica.com > topic > institutionaliz... 
17. Choi H. Institutionalization of Trust as Response to Globalization: The Case of Consumer Cooperatives in South Korea. Transition Studies Review. 2009. Vol. 16. P. 450-461.

18. The Global Competitiveness Report 2019. World Economic Forum. URL : http://www3.weforum.org/docs/WEF_TheGlobalCompetitivenessReport 2019.pdf.

19. GCI 4.0: Pillar 1: Institutions. URL : https://tcdata360.worldbank. org/indicators/h2bc5566c.

20. Kliesen L. Uncertainty and the Economy. Monday, April 1, 2013.

21. Altig D., Scott B., Barrero J. M., Bloom N., Bunn P., Chen S., Davis S. J., Meyer B., Mihaylov E., Mizen P., Parker N., Renault T., Smietanka P. and Thwaites G. Economic Uncertainty Before and During the COVID-19 Pandemic. Bank of England Staff Working Paper. 2020. №876. URL : https://voxeu.org/article/economic-uncertainty-wake-covid-19-pandemic.

22. Real-time economic analysis of the COVID-19 crisis: Lessons from Finland Helsinki Graduate School of Economics Situation. Room 21. May 2020. URL : https://voxeu.org/article/real-time-economic-analysis-covid19-crisis-lessons-finland\#sitcom.

23. Stolper W., Arbor A. A. Method of Constructing Community Indifference Curves. URL : http://www.sjes.ch/papers/1950-II-4.pdf.

24. Report from the commission on european governance. Luxembourg: Office for Official Publications of the European Communities. 2003. URL : https://ec.europa.eu/governance/docs/comm_rapport_en.pdf.

25. Rhodes R. The New Governance: Governing without Government. Politico1 Stiidia. 1996. XLIV. P. 652-667. URL : http://spp.xmu.edu.cn/wpcontent/uploads/2013/12/The-New-Governance-Governing-withoutGovernment-pdf.pdf.

26. Kohler-koch B., Rittberger B. Governance Turn' in EU Studies. JCMS. 2006. Vol. 44. P. 27-49. URL : https://ceses.cuni.cz/CESES-136version1-4C_Governance_turn_EU_kohler_rittberger_2006.pdf.

27. Klijn E., Koppenjan J. Governance Network Theory: Past, Present and Future. Policy and Politics. Vol 40(4). P. 187-206. URL : https://www.researchgate.net/publication/272138186_Governance_Network_ Theory_Past_Present_and_Future.

28. Lee M. Conceptualizing the New Governance: A New Institution of Social Coordination. Presented at the Institutional Analysis and Development Mini-Conference. 2003. May 3rd and 5th. URL : http://citeseerx.ist.psu.edu/viewdoc/download?doi=10.1.1.202.1474\&rep=re p1\&type $=$ pdf.

29. Saxena K. B. Ch. Towards excellence in e-governance. International Journal of Public Sector Management. №18(6). P. 498-513. URL : https://www.researchgate.net/publication/235271643_Towards_ excellence _in_e-governance. 
30. Політична економія суспільного прогресу Всеволода Голубничого. Вибрані праці. Відповідальний редактор д.е.н., професор Н. А. Супрун. Київ : Наукова думка, 2019. Том 2. С. 109-121.

31. Злупко С. М. Історія економічної теорії. Київ : «Знання», 2005. 719 c. C. $354-372$.

32. Панченко В. Економічна стратегія ОУН 1920 - 1950-ті рр.: розробка та реалізація. Інститут української археографії та джерелознавства НАН України. Київ, 2011. С. 6-12.

33. Економічний націоналізм та соціальна справедливість: збірник матеріалів / Упор. Т. Бойко, Ю. Сиротюк, Б. Галайко, К. Денисов. К. : НАЦ «УССД», «Видавець Олег Філюк», 2019. 320 с.

34. Sacks A. Why the Early German Socialists Opposed the World's First Modern Welfare State. 2019. URL : https:www.jacobinmag.com/2019/ 12/otto-von-bismarck-germany-social-democratic-party-spd.

35. Sagers J. H. Confucian Capitalism: Shibusawa Eiichi, Business Ethics, and Economic Development in Meiji Japan. The Quarterly Journal of Austrian Economics. 2019. Vol. 22. No. 1. P. 91-99. URL : https://mises.org/library/confucian-capitalism-shibusawa-eiichi-businessethics-and-economic-development-meiji-japan.

36. Brouard S., Mazur A. The French Fifth Republic at Fifty: Beyond Stereotypes. 2009. URL : https://www.researchgate.net/publication/ 302014813_The_French_Fifth_Republic_at_Fifty_Beyond_Stereotypes.

37. Berk Nation-Building, Party-Strength, and Regime Consolidation: Kemalism in Comparative Perspective. Turkish Studies. №15:4. 2014. P. 600-620. URL : https://www.tandfonline.com/doi/full/10.1080/14683849.2014. 986318? scrol l=top\&needAccess $=$ true.

38. Glyptis A-L Kemalism as a Language for Turkish Politics: Cultivation, Reproduction. Negotiation. URL : http://etheses.lse.ac.uk/423/1/ Glyptis_Kemalism\%20as\%20a\%20language\%20for\%20Turkish\%20politics.pdf.

39. Haggard St., Byung-Kook Kimand, Chung-in Moon. The Transitionto Export-Led Growthin South Korea: 1954-1966. The Journal of Asian Studies. 1990. URL : https://www.researchgate.net/publication/ 23723634_The_Transition_to_Export-led_Growth_in_South_Korea_1954-1966.

40. Maiorano D., Torri T. India 2014: the annihilation of the congress party and the beginning of the Modi era Home. The Journal Asia Maior. Vol. XXV. 2014. URL : https://www.asiamaior.org/the-journal/07asia-maior-vol-xxv-2014.

41. Davis K. Paul Kagame and Rwanda: an economic model for Africa. Ventures for Africa. June 15. 2014. URL : http://venturesafrica.com/ blog/2014/06/15/paul-kagame-and-rwanda-an-economic-model-for-africa/.

42. Country Profile - Rwanda by the Economic Commission for Africa. Publications Section. Economic Commission for Africa. URL : https://www.uneca.org/sites/default/files/images/ORIA/CP/rwanda.pdf. 